\title{
External Factors Influencing the Cognitive Response of Impulse Buying Behaviour amongst Generation Y Students
}

\author{
Jacinta Ana Neves, Ephrem Habtemichael Redda, Natasha de Klerk \\ North-West University (Vaal Triangle Campus), South Africa \\ Jacintaananeves1992@gmail.com, Ephrem.Redda@nwu.ac.za, Natasha.deKlerk@nwu.ac.za
}

\begin{abstract}
Impulse buying behaviour has been recognised as a key research concern amongst academic researches and marketers. At one time or another a large amount of consumers purchases on impulse. Evidence from the literature indicates that external factors, such as in-store atmosphere, in-store browsing, in-store layout, salespersons, promotions and reference groups are important antecedents of impulse purchases. The cognitive response to act on impulse purchase is triggered by external factors to buy on impulse. This paper reports on a study undertaken to determine the external factors influencing the cognitive response of impulse buying behaviour amongst Generation Y students. Generation Y are labelled as individuals born between 1986 and 2005. The study employed a quantitative method, whereby a structured, self-administered questionnaire was used to collect data from a non-probability convenience sample of 349 students (aged 18 to 24 years), across two South African public higher education institutions' campuses located in the Gauteng province. The collected data was examined using descriptive statistics, confirmatory factor analysis, reliability, correlation analysis and regression analysis. The coefficient of multiple determination (R2) was 0.070 that implies that in-store atmosphere, in-store browsing and promotions can predict seven percent of the variance in Generation Y students' cognitive response to buy on impulse, which proposes that other variables influence Generation Y students' cognitive response to buy on impulse.
\end{abstract}

Keywords: Impulse buying, cognitive response, external factors, consumer behaviour, Generation $Y$

\section{Introduction}

Impulse buying is a powerful marketing tool to increase retail sales, as it aids to a vast number of products sold in the retail environment (Das \& Das, 2015). In certain product categories, impulse buying accounts for almost 80 percent of purchases (dot Activ, 2016). Impulse products are characterised as products that are priced at a low-cost, are purchased frequently and which require minimum planning from consumers (Rook \& Hoch, 1985). Typically, impulse products include products such as food, clothing, shoes, books, beauty products, accessories and stationary (Hall, 2018; Garcia, 2018). Notably, evidence from the literature suggests that, 88 percent of impulse purchases are made due to items being offered on sale or promotion and impulse buys increase by 23 percent when the shopping trip itself is unplanned (Beta Bait, 2013). In 2013, on average, R13.5 billion a month was spent on impulse items by South African consumers (Times Live, 2014). Consumer behaviour is the actions consumers expose while investigating, purchasing, consuming, evaluating and disposing of products and services that are required to achieve the consumer's needs (Schiffman et al., 2010). Focusing on buying behaviour, different types of buying decision behaviour include habitual buying behaviour, variety-seeking buying behaviour, dissonance-reducing behaviour, complex buying behaviour and impulse buying (Mäkinen, 2015).

Impulse buying is an unexpected decision to purchase a product, which is made just before the end of the shopping trip (Taushif \& Gupta, 2013). According to Mathai and Haridas (2014), impulse buying behaviour is illogical as well as a lack of understanding and thinking. As a result, consumers who buy on impulse regret the purchase that has been made (Hausman, 2000). Impulse buying behaviour relates to a consumers affective and cognitive response to purchasing on impulse (Dawson \& Kim, 2009). The affective response relates to the consumer's positive buying emotions, mood management and uncontrollable desire to purchase (Sharma, 2012). Karbasivar and Yarahmadi (2011) stated that cognitive response is an internal factor that consumers can control. For the purpose of this study, reported on in this paper, the focus is on consumer's cognitive response. Various external factors may trigger impulse buys in consumers (Kalla \& Arora, 2011; Muruganantham \& Bhakat, 2013; Vishnu \& Raheem, 2013) and are therefore essential to marketers and retailers to take cognisance of (Dawson \& Kim, 2009). 
Objectives of this Study: The primary objective of this study was to determine the External Factors Influencing the Cognitive Response of Impulse Buying Behaviour of South African Generation Y Students in order to guide the formation of marketing strategies for targeting this market effectively. In accordance with the primary objective, determining whether the external factors of in-store atmosphere, in-store browsing, in-store layout, salespersons, promotions and reference groups' influence Generation Y students' cognitive response to buy on impulse was formulated as an empirical objective for this study.

Importance of this Study: Due to the growing nature of impulse buying, it is important for retailers and marketers to understand which external factors influence generation Y students' cognitive response in South Africa. Retailers and marketers can use the information from the study and implement the necessary strategies in the store to increase impulse buying, which ultimately increases revenue. This study will help retailers and store owners to gain a competitive advantage by implementing the strategies to attract consumers. This study contributes to the world of marketing as it was the first of its kind in South Africa and therefore can answer some questions retailers, marketers and store owners would like to know. Furthermore, findings from this study can contribute to academic research on consumer shopping behaviour amongst Generation Y students.

\section{Literature Review}

Impulse Buying Behaviour: Impulse buying in its simplest form can be explained as a purchase that is not planned. Impulse buying is experienced when consumers accumulate emotions over an item, which then leads to the item being purchased without much thought (Gamage et al., 2008). Cant et al. (2009) opine that a planned action takes place in the consumer decision-making process, whereas an unplanned action takes place in the impulsive decision-making process. Furthermore, once a decision has been made an action follows and to a consumer it appears that the planning did not follow the action. Similarly, Strydom et al. (2000) stated that impulse buying could not be regarded as an unplanned approach when shopping but rather an action made at that exact point of purchase. A consumer who is aware of a need that is not satisfied will engage in impulse buying but may not realise it at the point of purchase. The most influential part of impulse buying is a consumer's internal differences concerning an impulsive act (Chen, 2008). Impulse buying behaviour can be influenced by personality related factors of the consumer rather than the shopping environment. Therefore, marketers and retailers can utilise the characteristics of consumers to a minor extent, however, marketers and retailers cannot control consumers completely (Žnideršić et al., 2014). Patil and Agadi (2016) concur by stating that consumer's internal traits motivate the consumer to engage in impulse buying behaviour. The concept referred to as the buying impulsiveness trait is described as a tendency the consumer experiences when impulse shopping (Rook \& Fisher, 1995). Although consumer's personality traits (cognitive response) and the consumer's emotional state (affective response) are important, a number of external factors are implemented to trigger the consumer to purchase on impulse (Kannan \& Vinayagamoorthy, 2014).

Cognitive Response: Dincer (2010) defined the cognitive response as lack of planning when a decision to purchase is made Consumer's mental structures and processes involved in reflecting and interpreting is referred to as the cognitive response (Sharma, 2012). In addition, when a consumer has experienced a product, a combination of the consumer's knowledge, cognition and perceptions developed to assist in the purchase. A number of external factors influence the cognitive response of consumers.

External Factors: From the literature, in-store atmosphere (Vishnu \& Raheem, 2013; Hussain \& Ali, 2015; Nishanov \& Ahunjonov, 2016, Akram et al., 2016), in-store browsing (Vänniä, 2013; Kim, 2003; Sangalang et al., 2017), in-store layout (Shivangunde et al., 2012; Bitner, 1992; Ohta and Higuchi, 2013; Levy \& Weitz, 2011), salespersons (Evans et al., 2008; Shojaei et al., 2014; Ahuja, 2015), sales promotion ((Jamal \& Lodhi, 2015; Lin, 2013) and reference groups (Mothapo, 2013; Kumar, 2007; Tinne, 2011; Gandhi et al., 2014) where identified as essential external factors influencing consumers cognitive response to purchasing on impulse. Dynamics within the stores presentation (for example, noise, the backdrop, fittings, odour, the level of atmosphere and lights) is referred to as in-store atmosphere. These dynamics within the store influence the response of consumers for in-store and future store decisions (Vishnu \& Raheem, 2013). Music is an important variable which induces the consumer's mood, takes place at a subliminal level and creates a 
positive impact on impulse buying (Akram et al., 2016). According to the findings of Mattila and Wirtz (2001), good background music entices consumers to stay in the store longer to browse. Consumer's awareness is activated when there is a good melody playing in the background; this in essence increases impulse buying. Another factor that influences consumer's purchasing intention is store scent (Hussain \& Ali, 2015). The consumer increases impulse purchases when there is a pleasant aroma in the store as consumers will spend more time observing the products (Nishanov \& Ahunjonov, 2016).

In line with the findings discussed, the in-store atmosphere has a positive influence on Generation Y students' cognitive response to impulse buying. An important element of impulse buying behaviour is how consumers engage in in-store browsing, this entails when the consumers scan through items in the shop to be entertained and gain knowledge but with no intention to purchase an item. Consumers, who browse more in stores than those who do not, will purchase more on impulse; this is due to consumers being exposed to stimuli within the store (Vänniä, 2013). As a result, the consumers urge to buy on impulse increases (Kim, 2003). However, a study conducted by Sangalang et al. (2017) revealed that in-store browsing does not influence a consumer to buy impulsively. Well-designed sections and aisles within the store expose consumers to what the store has to offer within a given space, this is referred to as store layout (Shivangunde et al., 2012). Good store layout assists consumers to find the product quickly (Bitner, 1992). Creating convenience for consumers by means of a well-structured and organised store layout will improve the shopping process and impulse purchases (Ohta \& Higuchi, 2013). However, everyday products such as milk and bread are placed towards the back of the store; this encourages consumers to browse the store longer, which increases the possibilities of impulse buying (Levy \& Weitz, 2011). In line with this discussion, the instore layout is expected to positively influence Generation Y students' cognitive response to buy on impulse. A person who assists consumers to purchase items within the store is referred to as a salesperson (Cambridge University Press, 2016).

Helpful and friendly staff within the store encourages consumers to enjoy the shopping experience more. Salespeople can positively influence the shopping experience when good service is provided. However, an eager salesperson can scare away the consumers (Evans et al., 2008). The goal of the interaction between the consumer and salesperson is to convince the consumer that the purchase is the right decision (Shojaei et al., 2014). According to studies conducted the absence of a salesperson while shopping online decreases impulse buying. Thus, the salespersons' behaviour, selling techniques and presence does encourage the consumer to purchase on impulse (Ahuja, 2015). Sales promotion is utilised as a marketing tool to entice a consumer to purchase a product (Tutor $2 \mathrm{u}, 2015$ ). Impulse purchases are encouraged when items are at a promotional price or on discount. According to marketers, consumers worry about the future. Consumers purchase the product straightaway as consumers fear limited money available in the future; product availability or the promotion will not be available in the near future. Consumers are manipulated by deals such as scratch and win, stop and shop, buy two get one free, referral gifts, lucky draws and coupons. According to Jamal and Lodhi (2015) impulse purchases are realised when consumers buy more than needed. Based on published research sales promotions is expressed to have a positive influence on Generation Y students' cognitive response to impulse buying, reference groups are referred to as several different groups, for example. celebrities, religious groups, family and friends (Mothapo, 2013). Reference groups entail attitudes, knowledge, behaviour and values over different aspects (including buying behaviour) (Kumar, 2007). In the presence of others, buying on impulse is increased (Tinne, 2011). However, a study conducted by Gandhi et al. (2014) revealed that reference groups do not influence a consumer to buy impulsively.

Generation Y: Generation Y is regarded as individuals born between 1986 and 2005 (Markert, 2004). According to Acar (2014), Generation Y is also referred to as millennials or echo boomers. Generation Y members account for 40 percent of the population in South Africa (55 908000 individuals in 2016), which makes Generation Y members an important segment to market (Statistics South Africa, 2016). Due to the population size and spending power of Generation Y individuals, markets, retailers and researchers should pay close attention to this generation (Branchik, 2010; Yigit \& Aksay, 2015; Khan et al., 2016). Generation Y individuals experiment and adapt to new products in the market (Viswanathan \& Jain, 2013), therefore, this makes Generation Y individuals have high brand awareness, but are not brand loyal to the product (Noble et al., 2009) which creates a gap for buying on impulse. According to Kilber et al. (2014), the Generation Y student cohort are members aged 18 to 24 years old. 
Statistics show that a student spends on average around R3 510 per month, which amounts to R42 120 per annum (Sowetan Live, 2014). In 2016, the population size for South African students were around 1 million (Africa Check, 2016), with the potential to spend R39.5 billion per year, which makes Generation Y students an attractive market to target. Marketers and retailers need to understand and implement external factors to influence the cognitive response of impulse buying behaviour, as this will lead to Generation Y students buying more on impulse (Khan et al., 2016). The impulsive purchase could increase due to an older generation having a higher income then Generation Y students. According to previous research, credit cards were considered to play a role in impulse buying behaviour; however, this study did not determine the effect credit cards have on impulse buying behaviour.

\section{Methodology}

Research Design and Approach: This study followed a descriptive research design using a single crosssectional approach.

Sampling Method and Data Collection: The target population for this study entailed full-time Generation Y students aged 18 to 24 years who were registered at South African public HEIs in the Gauteng province during 2016. This study's sampling frame consisted of 26 registered South Africa public HEIs (Universities South Africa, 2016). A non-probability judgement sample of two HEI campuses (a University of Technology and a Traditional University) were chosen from this sampling frame. A drop-off approach was followed whereby 400 questionnaires were hand-delivered to the participating academic staff members of the two HEIs were circulated to the students for voluntary completion.

Research Instrument: For the purpose of this study, a standardised self-administered questionnaire was utilised to gather the required data. This survey questionnaire comprised two sections. The first section requested the sample participants' demographic data and the second section contained scales from published studies measuring the influence of external factors on the cognitive response of impulse buying behaviour. The Verplanken and Herabadi (2001) scale was adopted to measure the respondent's cognitive response to impulse buying behaviour comprising 10 items. The Cho et al. (2014) scale was adopted to measure the external factors influencing the cognitive response of impulse buying behaviour, comprising 23 items. A sixpoint Likert scale was utilised to measure the sample's responses.

Ethical Considerations: Prior to distributing the questionnaires, it was submitted for approval and ethical clearance to the Ethics Committee of the Faculty of Economic Sciences and Information Technology at the North-West University (Vaal Triangle campus). The questionnaire was deemed low risk and ethical clearance was granted (Ethical Clearance Number: ECONIT-2016-020).

Data Analysis: The IBM Statistical Package for Social Sciences (SPSS), Version 23.0 for Windows was utilised to analyse the captured data. The statistical analysis included principal component analysis, internalconsistency reliability, Pearson's Product-Moment correlation analysis and bivariate regression analysis.

\section{Results and Discussion}

The amount of 400 questionnaires were administered and 392 completed questionnaires were returned, which translates into a 98 percent response rate. Questionnaires were rejected if the students were younger than 18 or older than 24, if the student was a non-South African and if there was more than 10 percent missing values on the questionnaire. Therefore, this left 349 questionnaires, translating in an actual response rate of 87 percent. The University of Technology returned 160 questionnaires and the Traditional University returned 189 questionnaires. Table 1 indicates the sample description utilised in this study. 
Table 1: Sample Description

\begin{tabular}{llllll}
\hline & Percent (\%) & & Percent (\%) & Percent (\%) \\
\hline Age & & Language & & Province & \\
18 & 3.2 & Afrikaans & 11.2 & Eastern Cape & 2.3 \\
19 & 16.0 & English & 7.4 & Free State & 14.3 \\
20 & 24.0 & IsiNdebele & 0.9 & Gauteng & 56.7 \\
21 & 26.4 & IsiXhosa & 5.7 & KwaZulu-Natal & 2.9 \\
22 & 16.6 & IsiZulu & 14.3 & Limpopo & 11.5 \\
23 & 10.0 & Sepedi & 7.2 & Mpumalanga & 3.7 \\
24 & 4.6 & SeSotho & 27.8 & Northern Cape & 0.3 \\
Gender & & Setswana & 13.0 & North-West & 7.4 \\
Female & 57.6 & SiSwati & 2.0 & Western Cape & 0.3 \\
Male & 42.1 & Tshivenda & 5.0 & & \\
Ethnic Group & & Xitsonga & 4.0 & & \\
African & 83.5 & & & & \\
Coloured & 2.0 & & & & \\
Indian/Asian & 0.3 & & & & \\
White & 14.3 & & & & \\
\hline
\end{tabular}

Principle component analysis, using direct Oblimin rotation was performed on the scaled items to check the factor structure of the constructs used in the study. The factorability of the data was assessed using the Kaiser-Meyer-Olkin (KMO) measure of sampling adequacy and the Bartlett Test of Sphericity, where a KMO value exceeding 0.6 and a significant Bartlett's Test of Sphericity value are recommended (Pallant, 2010; Field, 2009). The results of these two tests yielded a KMO value of 0.839 and a significant Bartlett's test of sphericity (chi-square $=3617.113 \mathrm{dfs}, p \leq 0.01$ ), indicated the sampling adequacy and factorability of the data. The eigenvalues were used in determining the factors that influence the cognitive response of impulse buying behaviour. Factors with an eigenvalue of less than 1.0 were not considered (Malhotra, 2010). Hence, six factors were extracted that explained 56 percent of the variance. One factor, pertaining to in-store layout, did not emerge with an eigenvalue greater than 1.0 and therefore, was not considered. In Table 2, the varimaxrotated factors, eigenvalues and variance extracted for the extracted factors are presented.

Table 2: Rotated Factors, Eigenvalues and Percentage Variance Extracted

\begin{tabular}{|c|c|c|c|c|c|c|}
\hline Items & Factors & & & & & \\
\hline & 1 & 2 & 3 & 4 & 5 & 6 \\
\hline R1 & & .711 & & & & \\
\hline $\mathrm{R} 2$ & & .613 & & & & \\
\hline 3 & & & & .425 & & \\
\hline R4 & & 683 & & & & \\
\hline R5 & & .766 & & & & \\
\hline 6 & & & & .523 & & \\
\hline R7 & & .603 & & & & \\
\hline R8 & & .775 & & & & \\
\hline 9 & & & & .771 & & \\
\hline 10 & & & & .642 & & \\
\hline 11 & & & & & .372 & \\
\hline 12 & & & & & .826 & \\
\hline 13 & & & & & .869 & \\
\hline 14 & & & & & .458 & \\
\hline 15 & & & & & & .793 \\
\hline
\end{tabular}


$18 \quad .885$

$19-796$

$20 \quad .743$

$21 \quad .686$

$22 \quad .801$

$23 \quad .741$

$24 \quad .736$

$25 \quad .667$

$26-.704$

$27 \quad .257$

$28 \quad .398$

29

\begin{tabular}{lllllll} 
Eigenvalue & 6.235 & 3.656 & 2.282 & 1.512 & 1.346 & 1.185 \\
Percentage variance & 21.499 & 12.605 & 7.867 & 5.215 & 4.640 & 4.087 \\
\hline
\end{tabular}

Although values indicated in bold did not load as expected, there was no sufficient evidence to disregard Verplanken and Herabadi (2001) and Cho et al. (2014) factor models. The mean values and standard deviations for each factor were calculated. In order to assess the internal consistency reliability of the constructs were computed. This was followed by constructing a correlation matrix of Pearson's Product Moment correlation coefficients. The descriptive statistics, reliability and correlation coefficients are presented in Table 3.

Table 3: Descriptive Statistics, Reliability Measures, and Correlation Coefficients

\begin{tabular}{lllllllll}
\hline Constructs & Means & Std Dev & Cronbach Alpha & F2 & F3 & F4 & F5 & F6 \\
\hline $\begin{array}{l}\text { Cognitive } \\
\text { response }\end{array}$ & 3.09 & 1.41 & .795 & & & & & \\
$\begin{array}{l}\text { In-store } \\
\text { atmosphere }\end{array}$ & 4.32 & 1.22 & .741 & 1 & & & & \\
In-store browsing & 4.15 & 1.40 & .772 & $.165^{* *}$ & 1 & & & \\
Salespersons & 4.44 & 1.18 & .824 & $.132^{* *}$ & $.203^{* *}$ & 1 & & \\
$\begin{array}{l}\text { Promotions } \\
\text { Reference groups }\end{array}$ & 4.51 & 1.21 & .841 & $.507^{* *}$ & $.267^{* *}$ & $.246^{* *}$ & 1 & \\
** Correlation is significant at the 0.01 level (2-tailed) & 1.39 & $.234^{* *}$ & $.243^{* *}$ & $.283^{* *}$ & $.245^{* *}$ & 1 \\
\hline
\end{tabular}

As indicated in Table 3, the mean values for each of the constructs were above 3, which given the six-point Likert scale utilised, indicates that Generation Y students feel that good service, helpful salespersons, the more time spent in the store, having companionship during the shopping trip and the ambience of the store encourages an impulse purchase. Iacobucci and Churchill (2010) stated that the Cronbach coefficient alpha is the most commonly utilised statistic to measure internal consistency. A coefficient will vary from zero to one, but value of less than 0.6 suggests weak internal consistency reliability (Malhotra, 2010). Majority of the constructs feel above the 0.6 threshold; however, reference groups was slightly below the recommended level of 0.60. According to Pallant (2010), it is recommended to report on the average inter-item correlation value if a scale has less than 10 items. An average inter-item correlation for reference groups was 0.315 , which fell within the range of 0.15 and 0.50 and therefore accepted (Clark \& Watson, 1995). When performing any type of multivariate statistical method, it is important to evaluate if there is any evidence of multicollinearity between the predictor variables.

Therefore, in order to assess the relationships between the factors a correlation analysis was conducted in order to check for multicollinearity. As shown in Table 3, none of the correlation coefficients between the 
predictor variables surpassed the recommended cut-off point of 0.80 (Field, 2009). In addition, the collinearity diagnostics revealed that the tolerance values ranged between 0.642 and 0.811 , which is above the 0.10 cut-off level. Moreover, the variance inflation factor (VIF) ranged between 1.233 and 1.557, which was below the cut-off level of 10 (Pallant, 2010). As such, there is no suggestion of any apparent evidence of multicollinearity between the predictors and therefore regression analysis was conducted. A bivariate regression analysis was conducted to determine the influence of external factors on the cognitive response of Generation Y students. Table 4 reports the regression analysis conducted to ascertain whether the external factors, namely: in-store atmosphere, in-store browsing, salespersons, promotions and reference groups' influence Generation Y students' cognitive response to buy on impulse.

Table 4: Influence of External Factors on Cognitive Response

\begin{tabular}{lllll}
\hline & Standardised Beta & $\mathbf{R}^{\mathbf{2}}$ & t-value & Significance level \\
\hline $\begin{array}{l}\text { Dependent variable: } \\
\begin{array}{l}\text { Cognitive response } \\
\text { Independent variable: }\end{array}\end{array}$ & 0.070 & & \\
$\begin{array}{l}\text { In-store atmosphere } \\
\text { In-store browsing }\end{array}$ & .121 & & 2.165 & $.031^{*}$ \\
Salespersons & -.231 & & -4.283 & $.000^{*}$ \\
Promotions & .021 & & .379 & .705 \\
Reference groups & .145 & & 2.582 & $.010^{*}$ \\
$*$ Significant at p<0.05 & -.101 & & -1.844 & .066 \\
\hline
\end{tabular}

As shown in Table 4, in-store browsing and reference groups negatively affected the cognitive response however; most of the external variables had a positive influence on the cognitive response dimension of impulse purchasing Subject to in-store browsing, this negative influence is also significant. This implies that the Generation Y cohort members will not purchase impulsive goods when the time is spent browsing the items on display in a retail store. As shown in Table 4 , in-store atmosphere $(\beta=0.121, p=0.031<0.05)$ and promotions $(\beta=0.145, p=0.010<0.05)$ had a statistically positive influence towards Generation $Y$ students' cognitive response to buying on impulse while, salespersons $(\beta=0.021, p=0.705>0.05)$ did not have a statistically positive influence. The coefficient of multiple determination (R2) was 0.070 that implies that instore atmosphere; in-store browsing and promotions can predict seven percent of the variance in Generation Y students' cognitive response to buy on impulse, which proposes that other variables can influence Generation Y students' cognitive response to buy on impulse.

Discussion: The purpose of this study was to determine the external factors influencing the cognitive response of impulse buying behaviour amongst Generation Y students. As elucidated earlier in-store atmosphere, in-store browsing and promotions were found to be significant; however, seven percent was too low to conclude that these were the only factors to have had an impact on Generation Y students' cognitive response of impulse buying behaviour. According to previous research, reference groups do not affect the cognitive response (Gandhi et al. 2014). Moreover, Gandhi et al. (2014) are of the opinion that a reference group does not encourage the consumer to engage in an impulsive purchase, as reference groups are only needed when the consumer is specifically looking for something, or advise on a certain item. Therefore, consumers already have a plan of action and not a mindset for unplanned purchases. When consumers find the store to have good music and a pleasant smell, they tend to be more impulsive (Eroglu \& Machleit, 1993; Mattila \& Wiltz, 2001; Hussain \& Ali, 2015; Nishanov \& Ahunjonav, 2016). Consumers who spend more time browsing in the store or retail outlet are exposed to more incentives offered in the store and therefore, will purchase more on impulse (Vänniä, 2013).

\section{Conclusion and Recommendations}

The importance of research on impulse buying has increased and marketing practitioners are keen in understanding the drivers of impulse purchases particularly the Generation Y cohort. Utilising the consumer's cognitive response will help researchers and marketers understand consumer's characteristics as this will ultimately guide consumers into buying on impulse. A number of external factors trigger a consumer's cognitive response; as external factors are outside the consumer's control. In an attempt to fill a gap in 
research in the South African context, this study has determined that although in-store atmosphere, in-store browsing and promotions were significant, these factors are not sufficient to be determinants of Generation $Y$ students' cognitive response of impulse buying behaviour. The results also revealed that salesperson and reference groups were found to have no significant influence on Generation Y students' cognitive response to impulse buying behaviour. Abbas and Bashir (2015) state that cognitive response does not have much influence to buy impulsively. Furthermore, consumers are more influenced by emotions to buy on impulse, known as affective response, whereas the cognitive response deals with cognitive deliberation, unplanned buying and disregard for the future. Dincer (2010) explained that demographics used in one's study can also influence the results of impulse buying behaviour and therefore the results cannot be relied on the demographics alone. Due to this study using Generation Y students, businesses and marketers cannot rely on in-store atmosphere, in-store browsing and promotions to be the only factors to influence the cognitive response of impulse buying amongst this generation.

Like all academic studies, limitations were found in this study, which could suggest new opportunities for future research. Research conducted in this study employed a quantitative approach. Utilising the survey method to identify exactly what external factors influence the cognitive response of impulse buying behaviour is difficult. Different factors could have been analysed directly if Generation Y students were mindful to the responses experienced in the environment of a shop. Therefore, qualitative (for example, observation method) and quantitative research combined is suggested. This study focused only on two HEIs in one province. Therefore, a similar study could be conducted by including other HEIs in other provinces. This will lead to accurate results and comparisons can be made throughout South Africa's HEIs. Another limitation to this study was utilising only Generation Y students, aged 18 to 24 years. A similar study could target an older generation (30-50). This provides an opportunity to determine whether credit cards could be a factor influencing the cognitive response of impulse buying behaviour amongst Generation Y students.

\section{References}

Abbas, A. \& Bashir, B. (2015). Impact of the cognitive and affective process of decision making on impulse purchase. Institute of Business and Management, 27(1), 467-473.

Acar, A. B. (2014). Do intrinsic and extrinsic motivation factors different for Generation X and Generation Y. International Journal of Business and Social Science, 5(5), 12-20.

Africa Check. (2016). Student population in South Africa. https://africacheck.org/factsheets/factsheet-manysouth-african-students-graduate/ Date of Access: 7 June 2018.

Ahuja, D. (2015). Making the pulse impulsive: a study of factors resulting impulse buying. International Association of Scientific Innovation and Research (IASIR), 13(1), 50-52.

Akram, U., Hui, P., Khan, M., Hashim, M. \& Rasheed, S. (2016). Impact of store atmosphere on impulse buying behaviour: moderating effect of demographic variables. International Journal of $u$ - and e-service, service and technology, 9(3), 43-60.

Beta Bait. (2013). Impulse buying shopping fact sheet. http://betabait.com/the-impulse-shopping-fact-sheet/ Date of access: 8 February 2016.

Bitner, M. J. (1992). The impact of physical surroundings on customers and employees. The Journal of Marketing, 56(2), 57-71.

Branchik, B. J. (2010). Silver dollars: the development of the US elderly market segment. Journal of Historic Research in Marketing, 2(2), 174-189.

Cambridge University Press. (2016). Salesperson definition.

Cant, M. C., Strydom, J. W., Jooste, C. J. \& du Plessis, P. J. (2009). Marketing management. 5th ed. Cape Town, SA: Juta and company Ltd.

Chen, T. (2008). Impulse purchase varied by products and marketing channels. Journal of International Management Studies, 1, 154-161.

Cho, J., Ching, G. S. \& Luong, T. (2014). Impulse buying behaviour of Vietnamese consumers in supermarket setting. International Journal of Research Studies in Management, 3(2), 33-50.

Clark, L. A. \& Watson, D. (1995). Constructing validity: basic issues in objective scale development. Psychological assessment, 7(3), 309-319.

Das, S. P. \& Das, S. S. (2015). Impact of visual merchandising on consumers' impulse buying behaviour. The International Journal of Business and Management, 3(12), 188-201. 
Dawson, S. \& Kim, M. (2009). External and internal trigger cues of impulse buying online. Direct Marketing: An International Journal, 3(1), 20-34.

Dincer, C. (2010). The influence of affect and cognition on impulse buying behaviour. Social Responsibility Journal, 1, 153-158.

Dot Active. (2016). Impulse buying strategies. https://www.dotactiv.com/blog/merchandising-strategiesimpulse-buying Date of Access: 27 July 2018.

Eroglu, S. A. \& Machleit, K. A. (1993). Atmospheric factors in the retail environment: sights, sound and smells. Advances in Consumer Research, 20, 34.

Evans, M., Jamal, A. \& Foxall, G. (2008). Consumer Behaviour. John Wiley and Sons Ltd, Liber.

Field, A. (2009). Discovering statistics using SPSS. 3rd ed. London: Sage Publications Ltd.

Gamage, D. N. W., Wickramasingha, Y. M. \& Henegedara, G. M. (2008). Factors influencing impulse buying behaviour of rural people. Research and Training Institute, 1, 1-2.

Gandhi, A., Vajpayee, A. \& Gautam, D. (2014). A study of impulse buying behaviour and factors influencing it with reference to beverage products in retail stores. Journal of Symobios is Institute of Business Administration, 8, 1-17.

Garcia. (2018). Food tips list of impulse purchases.https://retail.emarketer.com/article/food-tops-list-ofimpulse-purchases/5a946479ebd4000744ae413d Date of Access: 21 July 2018.

Hall, A. (2018). Brits' top impulse buys revealed as study shows we spend $£ 144000$ in our lives on unplanned purchases. https://www.mirror.co.uk/money/personal-finance/brits-top-impulse-buys-revealed11856701 Date of Access: 21 July 2018.

Hausman, A. (2000). A multi-method investigation of consumer motivations in impulse buying behaviour. Journal of Consumer Marketing, 17(5), 403-426.

Hussain, R. \& Ali, M. (2015). Effect of store atmosphere on consumer purchase intention. International Journal of Marketing Studies, 7(2), 35-43.

Iacobucci, D. \& Churchill, G. (2010). Marketing Research: Methodological Foundations. 10th ed. SouthWestern Cengage Learning.

Jamal, M. \& Lodhi, S. (2015). Consumer shopping behaviour in relation to factors influencing impulse buying: a case of superstores in Karachi, Pakistan. European Journal of Business and Management, 7(31), 30-46.

Kalla, S. M. \& Arora, A. P. (2011). Impulse buying: a literature review. Global Business Review, 12(1), 145-157.

Kannan, P. \& Vinayagamoorthy, A. (2014). A study on influencing impulse buying behaviour. International Journal of Management and Social Science research review, 1(1), 19-27.

Karbasivar, A. \& Yarahmadi, H. (2011). Evaluating effective factors on consumer impulse buying behaviour. Asian Journal of Business Management Studies, 2(4), 174-181.

Khan, N., Hui, L. H., Chen, T. B. \& Hoe, H. Y. (2016). Impulse buying behaviour of Generation Y in fashion retail. International Journal of Business and Management, 11(1), 144-151.

Kilber, J., Barclay, A. \& Ohmer, D. (2014). Seven tips for managing Generation Y. Journal of Management Policy and Practice, 15(4), 80-91.

Kim, J. (2003). College students apparel impulse buying behaviours in relation to visual merchandising. Athens, Georgia: University of Georgia. (Thesis-Masters of Science).

Kumar, S. R. (2007). Marketing and branding. Bangalore, India: Pearson Education.

Levy, M. \& Wietz, B. A. (2011). Retailing management. 8th ed. Wisconsin, Madison: McGraw-Hill/Irwin.

Lin, E. (2013). External and internal factors of impulse buying behaviour in reference to gender. University Malaysia Sabah. (Masters-Thesis),

Mäkinen, T. (2015). Customers buying behaviour. Jamk University of Applied Sciences. (Thesis-PhD).

Malhotra, N. K. (2010). Marketing research: an applied orientation. 6th ed. Upper Saddle River, NJ: Pearson Education.

Markert, J. (2004). Demographics of age: generational and cohort confusion. Journal of current issues and research in advertising, 26(2), 11-25.

Mathai, S. T. \& Haridas, R. (2014). Personality - its impact on impulse buying behaviour among the retailer customers in Kochin city. IOSR Journal of Business and Management, 16(4), 48-55.

Mattila, A. S. \& Wirtz, F. (2001). Congruency of scent and music as a driver of instore evaluations and behaviour. Journal of retailing, 77(2), 273-289.

Mothapo, M. N. (2013). Importance of clothing brands on the purchasing decisions of Generation Y in the Vaal Triangle area. Vanderbijlpark: North West University. (Dissertation-Masters).

Muruganantham, G. \& Bhakat, R. S. (2013). A review of impulse buying behaviour. International Journal of Marketing Studies, 5(3), 149-160. 
Nishanov, B. \& Ahunjonov, U. (2016). The influence of store characteristics on consumer's impulse buying behaviour. Journal of International Business Research and Marketing, 1(3), 20-26.

Noble, S. M., Haytko, D. L. \& Phillips, J. (2009). What drives college age Generation Y consumers. Journal of Business Research, 62, 617-628.

Ohta, M. \& Higuchi, Y. (2013). Study on the design of supermarket store layouts: the principle of "sales magnet". International Journal of Social, Behavioural, Educational, Business and Industrial Engineering, $7(1), 209-212$.

Pallant, J. (2010). SPSS survival manual. 4th ed. London: Open University Press.

Patil, P. \& Agadi, R. (2016). Impact of visual merchandising on young customers" apparel impulse buying behaviour. International Journal of Advancement in Engineering, Technology, Management \& Applied Science, 3(1), 187-199.

Rook, D. W. \& Hoch, S. J. (1985). Consumer impulses. Advances in Consumer Research, 12, 23-27.

Rook, D. W. \& Fisher, R. J. (1995). Normative influences in impulsive buying behaviour. Journal of Consumer Research, 22, 305-313.

Sangalang, R. A., Siochi, J. \& Plaza, M. (2017). Factors Influencing Consumers' Impulse Buying Behavior in the Fifth District of Cavite. Paper presented at the DLSU Research Congress 2017, De La Salle University, Manila, Philippines, 20-22 June. http://www.dlsu.edu.ph/conferences/dlsu-research-congressproceedings/2017/EBM/EBM-I-005.pdf.

Schiffman, L. G., Kanuk, L. L. \& Wisenbilt, J. (2010). Consumer behaviour. 10th ed. Upper Saddle River, NJ: Pearson Prentice Hall.

Sharma, K. (2012). Impact of affective and cognitive processes on impulse buying of consumers. Rajkot: Saurashtra University. (Thesis-PhD).

Shivangunde, R. B., Shukla, R. K. \& Mehrotra, V. S. (2012). Organised retailing: retail store layout and design. Bopal: PSS Central Institution of Vocational Education.

Shojaei, M. R., Shahlaei, A., Torabi, S. \& Ghaedi, M. R. (2014). Investigating the effective factors on impulse buying. European Journal of Business and Management, 6(11), 62-64.

Sowetan Live. (2014). 10 things you didn't know about student spending. http://www.sowetanlive.co.za/news/business-news/2013/07/09/top-things-you-didn-tknowabout-student-spending Date of access: 16 October 2016.

Statistics South Africa. (2016). Mid year population estimates 2016 South Africa. http://www.statssa.gov.za/publications/P0302/P03022016.pdf Date of access: 16 October 2016.

Strydom, J. W., Cant, M. C. \& Jooste, C. J. (2000). Marketing management. 4th ed. Cape Town, SA: Juta.

Taushif, M. R. \& Gupta, M. (2013). A study of factors affecting impulse buying behaviour of consumers at malls (Dehli). International Journal of Research and Development - A Managerial Review, 2(2), 46-50.

Times Live (2014). Impulse buying statistics in rands. http://www.timeslive.co.za /thetimes/2014/05/27/impulse-buying-has-malls-smiling Date of access: 7 March 2016.

Tinne, W. S. (2011). Factors affecting impulse buying behaviour of consumers at Superstores in Bangladesh. ASA University Review, 5(1), 209-220.

Tutor $2 \mathrm{u}$. (2015). Sales promotion definition. http://www.ttor2u.net/business/reference/sales-promotion Date of Access: 22 August 2016.

Universities South Africa. (2016). Universities of South Africa. http://www.universitiessa.ac.za/publicuniversities-south-africa. Date of access: 30 March 2016.

Vänniä, E. (2013). Impulse buying behaviour of young males in an airport environment. International Business. (Thesis-Masters).

Verplanken, B. \& Herabadi, A. G. (2001). Individuals differences in impulse buying tendency: feeling and no thinking. European Journal of scientific Research, 15, 7183.

Vishnu, P. \& Raheem, A. R. (2013). Factors influencing impulse buying behaviour. European Journal of Scientific Research, 100(3), 67-79.

Viswanathan, V. \& Jain, V. (2013). A dual-system approach to understanding "Generation Y" decision making. Journal of Consumer Marketing, 30(6), 484-492.

Yigit, S. \& Aksay, K. (2015). A comparison between Generation X and Generation Y in terms of individual innovativeness behaviour: the case of Turkish health professionals. International Journal of Business Administration, 6(2), 106-117.

Žnideršić, R. K., Grubor, A. \& Marić, D. (2014). Impulsive consumer behaviour. International Journal of Multidisciplinary in Business and Science, 2(2), 81-89. 